\title{
Low Cost Community Housing Program: A case of Janata awash, Rupandehi Nepal
}

\author{
Er. Sandeep Parajuli ${ }^{1}$, Dr. Anjay Kumar Mishra ${ }^{2 *}$ \\ ${ }^{1}$ Assistant Professor, Oxford College of Engineering and Management, Gaidakot 2, Nawalpur, Nepal \\ ${ }^{2}$ Associate Professor and Research Director, Madan Bhandari Memorial Academy Nepal and Pokhara University Urlabari 3, Morang, Nepal
}

DOI: $10.36348 /$ sjet.2020.v05i09.001

| Received: 19.08.2020 | Accepted: 27.08.2020 | Published: 09.09.2020

*Corresponding author: Anjay Kumar Mishra

\section{Abstract}

Housing is constitutional right and human basic need. So, the objective of the paper to assess the status of housing need fulfilment for low income marginalized group. Questionnaire survey and interview were conducted with the selected, non selected construction completed and construction not started yet applicants of Program of the study area to assess the current housing scenario and their perception about the fulfilment of the housing need. Likewise the questionnaire survey and interview were carried out with planners, implementers and concerned organisations to find out the most important factors influencing the housing need of the low income groups (dalits and poor musalmans). Over 65\% of the people of the low income groups (dalits and poor musalmans) in the study area were found very poor housing condition and uneducated. The improvement in the education level brings awareness, better employment opportunity and consequently improves their economic status and housing condition. The major factors of housing need are as: Neighborhood and community attachment, Place of living currently, Geographical location, Easy access to the family's occupation, Family's income respectively to importance.

Keywords: Need, Factors, Condition of housing, Dalits and Muslims.

Copyright @ 2020: This is an open-access article distributed under the terms of the Creative Commons Attribution license which permits unrestricted use, distribution, and reproduction in any medium for non-commercial use (NonCommercial, or CC-BY-NC) provided the original author and source are credited.

\section{INTRODUCTION}

There are three basic needs for the human being; they are food, clothes and shelter. Housing being one of the basic need of the people, it is necessary to make the provision for providing the adequate housing facility to the people of all the groups including the people of low income group, poor and excluded group in order to pave the path for the sustainable and equitable development of the nation.

In Nepal, there is a tradition of constructing housing generally through self-efforts by utilizing own resources and means. However, the supply of housing to the majority of families, especially to the families who have marginal and low income, has become a complicated problem in the current situation. The housing problem seen in the urban and rural areas for the reasons, such as internal migration, rapid urbanization, increasing pressure of population, the families displaced by the conflict, natural calamities and degrading environment etc., appears to have become a serious challenge to the nation.
The Government of Nepal has implemented a special housing program called 'People Housing Program' (Janata Awash Karyakram) targeted especially for the dalits (untouchables) deprived and backward groups like Chepang, Bankariya and deprived class of Terai Madhesh (Southern Plain). The program was started in the Fiscal Year 066/067, and has adopted the policy of implementing this program also for the Raute, Kusunda as well as the badi communities.

The program is focused to the deprived class and marginalized ethnic groups of the society. And also government of Nepal has aim to construct 22647 units of house in whole country in last year [1].These houses are constructing under supervision of division office. This program is now widely spread in 74 districts of Nepal.

\section{Rational of the Study}

The need of inclusion is advocated in most of the sectors of Nepal, but its implementation is very weak in almost all the sectors. One of the reasons for the weak implementation of the inclusion might be the 
lack of willingness and commitment of the policy makers and the concerned bodies and the other reasons might be the complication in the implementation process of inclusion. In such a situation, the provision of adequate housing facilities for the poor becomes essential to take initiation towards the inclusion. Housing is the one of the basic need for all the people and the inclusion must be focussed in the process of providing the housing facilities to the people. Although there are many studies conducted regarding the need of housing in the Kathmandu Valley, but this type of studies have not been conducted on Rupandehi (outside valley district) the adequate housing facilities for the poor and low income group of people(specially for dalits and poor musalmans). This study will be useful to the policy makers, implementers of housing project and NGOs and local bodies.

This research will find how a little (effort) investment of Government in such Housing projects impacts a lot in the People's life socially and economically

\section{RESEARCH OBJECTIVE}

The objective of the paper to assess the status of housing need fulfilment for low income marginalized group that is dalit and poor muslims of Rupandehi district of Nepal.

\section{LITERATURE REVIEW \\ Housing Scenario}

Housing is one of the basic requirements for human survival. For a normal citizen owning a house provides significant economic and social security and status in society. For a shelter less person, a house brings about a profound social change in his existence, endowing him with an identity, thus integrating him with his immediate social milieu. It is one of the top priorities for most people, regardless of their income levels. Many poor village women consider housing as their most important need above food, health care and education for their children.

Without the security and comfort of home, there are no escaping difficulties resulting from poverty. Poor people do not have financial means to buy or construct houses with their saving and therefore they live in their ancestral huts, those rented from landlords (with ensuring obligation), or government supplied house.

Table-1: Housing Aspects

\begin{tabular}{|l|l|}
\hline Aspects & Description \\
\hline Single Family & $\begin{array}{l}\text { This kind of house where just one family lives in it and most likely with a fence } \\
\text { surrounding it is called a single-family house }\end{array}$ \\
\hline Manufactured Home & $\begin{array}{l}\text { This is the kind of house that is built at a factory and then transported to its final } \\
\text { destination. They are made in sections with some homes being just one section wide and } \\
\text { others being two or three sections wide. }\end{array}$ \\
\hline Condominium & $\begin{array}{l}\text { A condominium is one unit in a multi-unit building. This means that if you own a condo, } \\
\text { you probably share a wall or two with your neighbors }\end{array}$ \\
\hline Cooperative Housing & $\begin{array}{l}\text { Instead of purchasing their own house or condominium, prefer to purchase real estate } \\
\text { with a group of other people. This type of real estate ownership is referred to } \\
\text { as cooperative housing }\end{array}$ \\
\hline
\end{tabular}

((https://study.com/academy/lesson/types-of-housing-overview-examples.html))

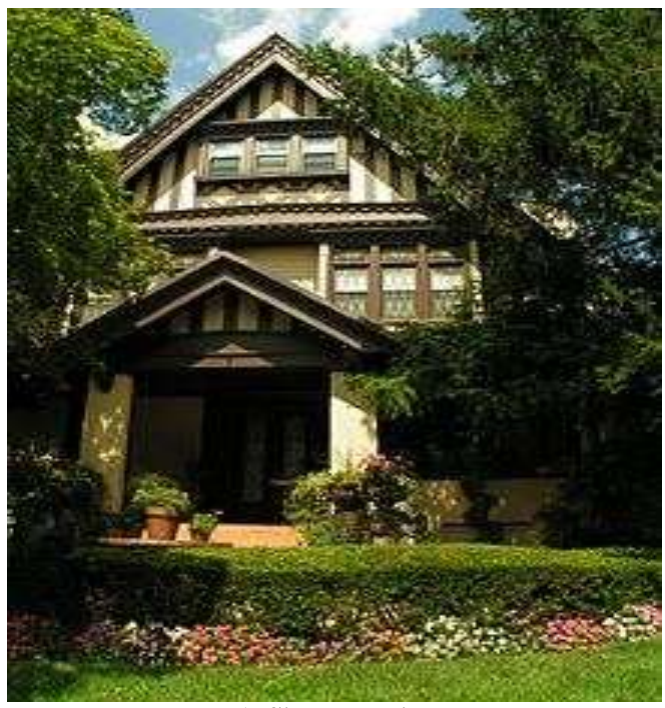

Photo-1: Single Family House

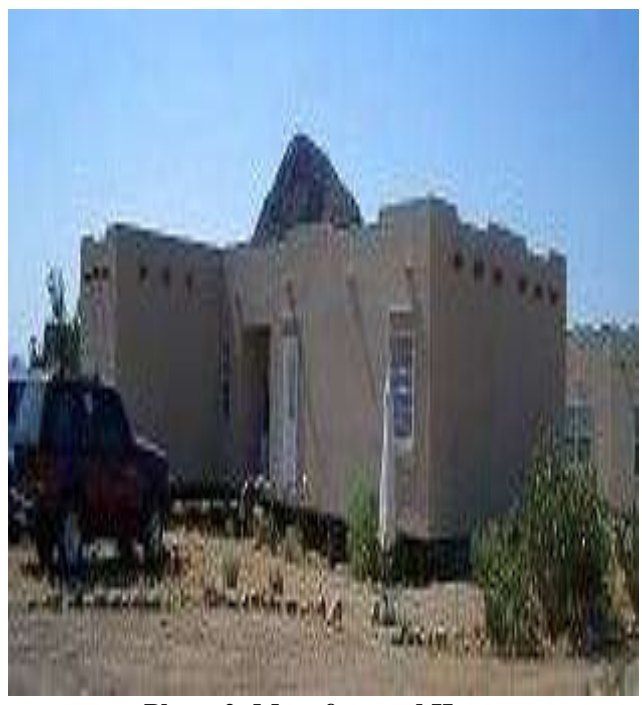

Photo-2: Manufactured Home 


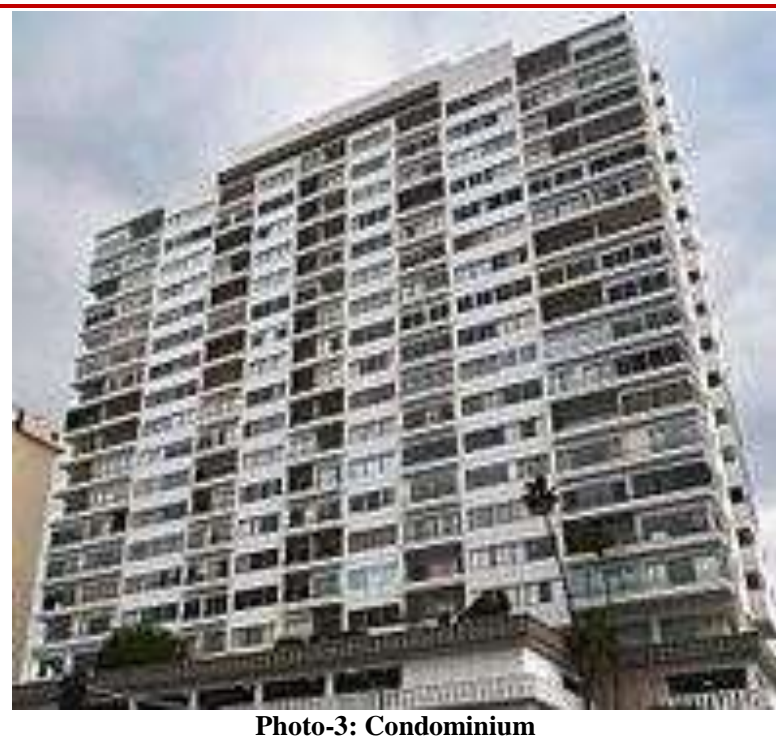

Photo-3: Condominium

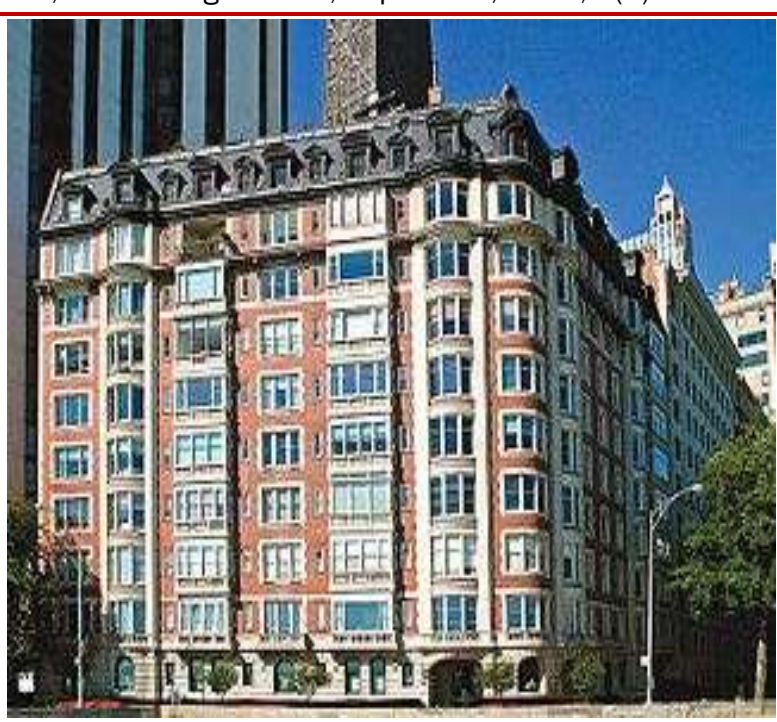

Photo-4: Cooperative Housing

Source: (Home base for Housing, 2015)

Different types of housing are as below:

Table-2: Type of Housing by Length of Stay

\begin{tabular}{|l|l|}
\hline Type of Housing & Description \\
\hline Permanent Housing & $\begin{array}{l}\text { This just means that there is no time limit on how long you can reside in the housing or } \\
\text { receive the housing assistance. It is meant to be long-term. "Permanent supportive } \\
\text { housing" (or PSH) is just permanent housing that makes support services available to help } \\
\text { you maintain your housing and access community resources. }\end{array}$ \\
\hline Transitional Housing & $\begin{array}{l}\text { This means that there is a time limit on how long you can stay in the housing or receive the } \\
\text { housing assistance. HUD defines transitional housing as stays of up to 24 months (but } \\
\text { stays can be shorter). }\end{array}$ \\
\hline $\begin{array}{l}\text { Short-Term or } \\
\text { Temporary Housing }\end{array}$ & $\begin{array}{l}\text { This means that the housing situation is intended to be very short-term or temporary (30, } \\
60 \text { or 90 days or less). }\end{array}$ \\
\hline Emergency Shelter & $\begin{array}{l}\text { Provides a place to stay or bed to sleep in overnight if you become homeless or otherwise } \\
\text { experience a housing crisis and have no place to go. }\end{array}$ \\
\hline
\end{tabular}

Source: (Home base for Housing, 2015)

\section{Table 3 Types of Housing by Level of Support}

\begin{tabular}{|l|l|}
\hline Type of Housing & Description \\
\hline Independent Living & $\begin{array}{l}\text { This means that you are able to live on your own without help with daily living. Most } \\
\text { housing is designed for independent living. }\end{array}$ \\
\hline Assisted Living & $\begin{array}{l}\text { This type of housing provides on-site services to help people with their daily living when } \\
\text { they are not really able to live on their own. It can be permanent or for a period of } \\
\text { time. Examples include: nursing homes, long-term care facilities, assisted living facilities, } \\
\text { special care facilities, and hospice/respite care facilities. }\end{array}$ \\
\hline
\end{tabular}

Source: (Home base for Housing, 2015) 


\section{Table-4: Types of Housing by Type of Assistance}

\begin{tabular}{|c|c|}
\hline Type of Housing & Description \\
\hline $\begin{array}{l}\text { Market Rate } \\
\text { Housing }\end{array}$ & $\begin{array}{l}\text { Refers to properties that are rented or owned by people who pay market rent to lease the } \\
\text { property or paid market value when they bought the property. There is no subsidy for the } \\
\text { housing. }\end{array}$ \\
\hline $\begin{array}{l}\text { Affordable Rate } \\
\text { Housing }\end{array}$ & $\begin{array}{l}\text { This type of housing provides on-site services to help people with their daily living when they } \\
\text { are not really able to live on their own. It can be permanent or for a period of time. Examples } \\
\text { include: nursing homes, long-term care facilities, assisted living facilities, special care } \\
\text { facilities, and hospice/respite care facilities. }\end{array}$ \\
\hline $\begin{array}{l}\text { Subsidized Housing } \\
\text { Housing (Tenant } \\
\text { Based) }\end{array}$ & $\begin{array}{l}\text { Provides a voucher to you to choose where you want to live in the community and lease from a } \\
\text { private landlord that will accept the voucher. The program then pays an ongoing monthly } \\
\text { subsidy to help you with your rent and utilities. You are usually required to pay at least } 30 \% \text { of } \\
\text { your income toward your rent and utilities, and usually your subsidy is limited by fair market } \\
\text { rent (FMRs). Since it is tenant-based, the assistance is tied to your voucher. So, if you move, } \\
\text { the voucher typically moves with you to another property. } \\
\text { Examples include these subsidy programs: } \\
\text { - Section } 8 \text { Housing Choice Voucher } \\
\text { - ESG Rapid Re-Housing } \\
\text { - HOPWA Tenant Based Rental Asst } \\
\text { - Shelter Plus Care TBRA } \\
\text { - SHP TBRA } \\
\text { - HOME TBRA }\end{array}$ \\
\hline $\begin{array}{l}\text { Subsidized Housing } \\
\text { (Project-Based) }\end{array}$ & $\begin{array}{l}\text { Project-based housing assistance requires you to live in a housing unit at the property that is } \\
\text { being subsidized. You are usually required to pay at least } 30 \% \text { of your income toward your } \\
\text { rent/utilities. Since it is project-based, the assistance is tied to the property. So, if you move, } \\
\text { you lose your housing assistance. Examples include: } \\
\text { - Section } 8 \text { Public Housing } \\
\text { - Homeless Project-Based Units } \\
\text { - HOPWA Facility-Based Housing }\end{array}$ \\
\hline $\begin{array}{l}\text { Homeless } \\
\text { Prevention }\end{array}$ & $\begin{array}{l}\text { Provides assistance for persons who have their own apartment or house to prevent them from } \\
\text { becoming homeless. This type of assistance helps with past due rent, mortgage, or utility bills. } \\
\text { Example include: } \\
\text { - ESG Homeless Prevention, HOPWA Short-Term Rent, } \\
\text { - Mortgage, and Utility Assistance (STRMU), } \\
\text { - Other Financial Assistance or Temporary Financial Aid Programs (e.g., assistance } \\
\text { provided by churches and other faith-based organizations) }\end{array}$ \\
\hline Housing Placement & $\begin{array}{l}\text { Provides help for you to get into new housing (when you move-in). This can include things like } \\
\text { rental application fees, security deposits, first and last month's rent, utility connection fees, and } \\
\text { utility deposits. Depending on the program, it may or may not include moving costs (like } \\
\text { moving company, truck rental, storage costs, etc.) }\end{array}$ \\
\hline
\end{tabular}

Source: (Home base for Housing, 2015)

Table-5: Types of Housing by Design

\begin{tabular}{|l|l|}
\hline Type of Housing & Description \\
\hline Multi-Family Dwellings & $\begin{array}{l}\text { This housing is designed for many families to live on the property where each family } \\
\text { only has exclusive use of the portion of the property (unit) that they are leasing or } \\
\text { own (for example, apartments, condominiums, lofts, and co-ops). }\end{array}$ \\
\hline Single Family Dwellings & $\begin{array}{l}\text { A single family dwelling refers to a dwelling (house) on a property designed to be } \\
\text { occupied by only one family }\end{array}$ \\
\hline $\begin{array}{l}\text { Single Room Occupancy } \\
\text { (SRO) }\end{array}$ & $\begin{array}{l}\text { An SRO unit is a single room designed to house only one person at a time. It may be } \\
\text { smaller than a typical bedroom, and may only include a bed and storage space for } \\
\text { personal belongings. An SRO unit provides living and sleeping space for the exclusive } \\
\text { use of the tenant, but requires the tenant to share bathroom and/or kitchen areas. }\end{array}$ \\
\hline $\begin{array}{l}\text { Manufactured Home (or } \\
\text { Mobile Home) }\end{array}$ & $\begin{array}{l}\text { A manufactured home is a mobile home that is connected to permanent utility hookups, } \\
\text { is located on land is owned by the home owner or on land at which he/she leases a space } \\
\text { (such as a mobile home park), and is attached to real property (with a permanent } \\
\text { foundation). This includes mobile homes, but excludes motor homes, trailers, } \\
\text { recreational vehicles or RVs, and other like vehicles with wheels on the ground. }\end{array}$ \\
\hline
\end{tabular}


Sandeep Parajuli \& Anjay Kumar Mishra., Saudi J Eng Technol, September, 2020; 5(9): 316-329

\begin{tabular}{|l|l|}
\hline \hline $\begin{array}{l}\text { Boarding Homes, } \\
\text { Rooming Houses, or } \\
\text { Group Homes }\end{array}$ & $\begin{array}{l}\text { A boarding (or rooming) house is an establishment primarily engaged in renting rooms, } \\
\text { with or without board, on a long-term basis. A rooming house typically provides only for } \\
\text { the rental of rooms, while a boarding house provides meals and may offer such amenities } \\
\text { as maid service and laundry service. A boarding or rooming house may be a single } \\
\text { family dwelling or a larger structure in which the owner rents out rooms to multiple } \\
\text { families. They may be a lease. Group homes tend to look like boarding homes, but they } \\
\text { are typically a state-licensed facility intended for occupancy by elderly persons and/or } \\
\text { persons with disabilities. }\end{array}$ \\
\hline $\begin{array}{l}\text { Hotel or Motel (including } \\
\text { extended stay) }\end{array}$ & $\begin{array}{l}\text { A hotel or motel is an establishment primarily engaged in renting rooms for overnight } \\
\text { stays for a short period of time, but can be extended stays. The customer typically does } \\
\text { not have a written lease or occupancy agreement for the space. }\end{array}$ \\
\hline Shared Housing & $\begin{array}{l}\text { People who have a roommate are said to be living in "shared housing." For example, if } \\
\text { you share your 2-bedroom apartment with another person who is not part of your family, } \\
\text { then you are living in shared housing - meaning there are two families living there, you } \\
\text { and your roommate. This is important because, if you seek help with your housing } \\
\text { expenses, a program will likely only assist you with your part of the expenses, not your } \\
\text { roommate's part. }\end{array}$ \\
\hline
\end{tabular}

Source: (Home base for Housing, 2015)

Table-6: Types of Housing as Described in National Shelter Policy 2012

\begin{tabular}{|l|l|l|}
\hline SN & Types of Housing & Description \\
\hline 1 & Permanent Housing & $\begin{array}{l}\text { Permanent structure for purely residential purpose, the full ownership of which would } \\
\text { remain with the user. }\end{array}$ \\
\hline 2 & Common Housing & $\begin{array}{l}\text { Multi-story permanent structure for purely residential purpose, which would remain } \\
\text { under the common or joint ownership of two or more users. }\end{array}$ \\
\hline 3 & Mixed Housing & $\begin{array}{l}\text { Permanent structure for purely residential purpose, constructed so as to be able to carry } \\
\text { out nonresidential activities as well. }\end{array}$ \\
\hline 4 & Rental Housing & $\begin{array}{l}\text { Permanent structure for purely residential purpose, which require payment of charges for } \\
\text { using it and which does not remain under the ownership of the users. }\end{array}$ \\
\hline 5 & Temporary Housing & $\begin{array}{l}\text { The housing, which is made available to the families displaced by the reason of natural } \\
\text { calamities or conflict, before their permanent resettlement, as an immediate relief, and of } \\
\text { the types such as huts or camps that may be used only for some time. }\end{array}$ \\
\hline
\end{tabular}

Source: (National Shelter Policy 2012)

\section{The Low Income Groups}

According to the World Bank reports, the groups of people with daily income less than US $\$ 1.25$ are considered as the low income groups or the poor groups. There are also many other official standard definitions of the low income groups or the poor groups based on calorie intake and proportion of the expenditure on food (70\% of the expenditure on food) exists. One of the Indian Philosophers, Amartya Sen has stated that are five prime factors responsible for poverty, which are; (i) Over population, (ii) Imbalance of distribution of resource, (iii) Insufficient education, (iv) Low opportunity for employment and (v) Environmental degradation.

Similarly, Satterwaire in 2002 A.D., stated that there are eight aspects of poverty which provide a range of possible policy responses, and they are; (i) Shelter (ii) Provision of public infrastructures (iii) Income (iv) Asset base (v) Provision of social services (vi) Protection of public right through law enforcement (vii) Lack of safety net to ensure access to shelter and (viii) Powerless political system.
According to the Nepal Living Standard Survey [2], the estimation of poverty is based on the cost of the basic need approaches where the poverty line can be defined as the expenditure value (in terms of local currency), required by the individuals to meet their basic needs in terms of both food and non food items. By estimating the expenditure on food of the poor, the food basket of the poverty line is constructed. As there is a calorie anchor guiding the estimation of the food poverty line, no objective minimum non-food requirement exists a priori. Following the international standard, it is assumed that a household, whose food consumption is close to the food poverty line, will spend the minimum on the required minimum calorie requirement of 2,200 Kcal per day to fulfill the non food needs. In 2011 A.D., the average price of the poverty line was estimated as NRs. 19,261.00; the food poverty line as $11,929.00$ and the non food poverty line as NRs. 7,332.00. Whereas for the Kathmandu Valley, the average price of the poverty line was estimated as NRs. 40,933.00; the food poverty line as NRs. $26,323.00$ and the non food poverty line as NRs. $14,610.00[2]$. 
Regarding the composition, on average, $62 \%$ of the household consumption is spent on the food expenditures in the country. The Share of housing consumption is $11 \%$, that of education is $5 \%$ and the rest $22 \%$ is accounted for by other non-food items. However, the households of the Kathmandu valley tend to spend more on house, rent and education relative to the other urban and rural areas [2].

\section{Housing Needs for the Low Income Groups}

The pace of urbanization has remained faster and is likely to remain so in the future. Nearly, $17.1 \%$ of Nepal's population resided in 58 designated urban areas according to the 2011 census. However, with the addition of 131 municipalities in 2014, 38.26\% of Nepal's populations reside in 191 designated urban areas. There have been fluctuations in inter-censual urban growth rates. Although the growth rate in the inter-censual decade was $3.43 \%$, the average annual growth between 1981and 2011 has remained at a high rate of $5.3 \%$. Urban rural growth differential in 2011 is $2.4 \%[3]$.

Kathmandu valley is the hub of Nepal's urbanization. Over half of Nepal's urban populations reside in the hills and the rest in the Terai. The Central Development Region (CDR) including the capital region of Kathmandu harbors half of Nepal's urban population. The EDR and WDR share $17 \%$ - $18 \%$ of urban population each. Regional levels of urbanization differ markedly across ecological and development regions. The level of urbanization is highest in the hill region $(21.7 \%)$ compared to the Terai $(15.1 \%)$ and the mountains $(2.8 \%)$. Among development regions, CDR has highest urbanization level of $23.5 \%$. Distribution of urban population as well as the level of urbanization is relatively low in the MWDR and FWDR. Physiographic and connectivity characteristics are important determinants of urbanization which result wide variation in the regional levels of urbanization. The level of urbanization in the Kathmandu valley (three districts) and Pokhara valley (Kaski district) comes to $96.97 \%$ and $79.52 \%$ respectively, while it is only $18.28 \%$ for the rest of the hills. Similarly, inner Terai valleys have a level of urbanization of $41.97 \%$ compared to $38.94 \%$ for the rest of the Terai [3].

Urbanization picture is dominated by few large and medium cities. Kathmandu is the only city with over a million people. In terms of size class of urban centers, 14 urban centers ( 4 in the hills, 10 in the Terai) in 58 municipalities, and 2 urban centers (in the hills) in recently added 131 municipalities with over 100,000 population have $33.53 \%$ of Nepal's urban population. The rest $66.47 \%$ live in 175 municipalities. This distribution shows an urban hierarchy that is truncated towards the lower end notwithstanding the fact that urban boundaries are notorious both for including large rural tracts on the one hand, and ignoring urban sprawl beyond municipal boundaries, on the other. The fact that municipal status is a political decision rather than a technical one, it has also contributed to this picture, between 1991 and 2011 to the number of municipal areas [3].

After conducting the national housing survey in 1988 , no other survey regarding the housing has been conducted in Nepal. However, the conduction of housing in rural and urban areas has been presented in the subsequent censuses and living standard surveys of Nepal. According to the national housing survey of 1988, there were 3 million residential houses in Nepal including those urban and rural areas. A total of 47, 67,196 houses/buildings or residential structures have been found in the preliminary result of the national census 2011. A total of 56, 59,984 families appear to have settled there in. Thus, the ratio of family and houses has been 1.2:1. The number of families was 42, 53,200 ten years ago. In this way 10, 06,764 families appear to have been added during the last 10 years. In regard to the size of the family, there are 4.7 members per family in 2011, which were 5.44 in the year 2001 . 4.05 persons on average have been found in the families in the urban areas, while this number is 4.86 persons in the rural areas; this number was 4.86 and 5.65 persons respectively 10 years ago. In observing the population growth of the last ten years, it appears that the population of Nepal has increased by 15 percent, whereas the population of Kathmandu Valley appears to have been increased by 52 percent. In this way, it has now become indispensible to address the growing problem of housing in the Kathmandu valley [4].

According to the census of 2001, there was $41,74,374$ houses /buildings or residential structures in total, out of which about 1.3 million houses in the rural area and about 1 hundred thousand in the urban area were temporary in nature, which means that about 33 percent of the total residential houses appear to have been constructed in a temporary manner. According to the standard of living survey of Nepal, 2003/04, the population living in the houses of their ownership was about 91.6 percent and those living on rent was 5.4 percent, whereas, these numbers appeared to be 92.8 percent and 2.2 percent respectively in the year 1995/96. From the result of Fiscal Year 2009/10, these numbers appear to be 90 percent and 8 percent respectively. In this way, the number of population living in a rented house has increased from 2 percent to 8 percent compared to the first Standard of Living Survey, i.e. during the period of 15 years [4].

According to the Nepal Standard of Living Survey2003/04, the condition of housing in the urban areas appears to be better in the comparison to the same in rural areas. In the urban areas, it appears that about 72 percent families reside in their own houses, 23.5 percent on rent. 3.8 percent of the population lives without paying rent and the remaining in other ways such as unsystematic settlements (squatters). But in the 
case of Kathmandu Valley this number appears to be increasing surprisingly, about 35 percent of the population lives on rent in the Kathmandu Valley [4].

Whereas in 2011, it appears about 69.2 percent families reside in their own houses, 26.5 percent on rent and 4.3 percent of the population live without paying rent and the remaining in other ways such as unsystematic settlements (squatters) in the urban areas of Nepal. But in the case of Kathmandu District this number appears to be increasing surprisingly, about 51.9 percent of the population lives on rent in the Kathmandu Valley [2].

The number or population living on rent has been increased by 3 percent; the population living without paying rent by 0.4 percent and in unorganized shelter from 2003 to 2011. The number of population living on rent and in unorganized shelter is increasing fast since the last decade.

Nowadays, the valley is undergoing an urban explosion rather than managed urban growth. Urban areas are expanding at the rate of $6.67 \%$ annually at present. A statistical report of World Bank stated 23\% of urban population is poor \& live irregular and substandard housing with inadequate infrastructure and services. It is stated in the Directive Principles and the policies of the State in the constitution of Nepal: "The State shall pursue a policy of raising the standards of living of the general public through the development of infrastructures as education, health, housing and employment of the people" Housing has been identified as a national problem. There is a need to find solutions to address the problem [25].

Recent trends in the Housing sector shows that housing companies generally erect apartments within ring road while stand-alone houses that require wider space are built outside ring road. Increasing number of customers buy apartments as an investment rather than for self-consumption. Many buyers have been renting out apartments to ensure growth in the housing business; developers need to encourage buyers to live in the apartments. There is a substantial increment in the number of Companies and projects over the period of ten years. The number of Companies involved in this sector, within the valley currently stands at about 150 , according to the membership roaster of Nepal land \& Housing Developers Association. The no. of Companies registered as Housing Developers is about 40-50. Out of them, 8-10 companies are embarking on new projects after completing their previous ones, while some have launched their maiden projects and others are either on the pre-sales or sales of their maiden projects. Land \& Housing Development Act Issuances covering a wide range as Ownership rights of Customers Operational management Buyer's Duties Developers Liabilities etc Are mentioned and governed by Apartment Act 2003 and By-laws 2004 Registered Projects [6] According to this list, there are a total of 60stand-along housing units, registered after the year 2004. So, this number may increase in units. There are a total of 1697 apartment units registered according to this data. Obviously, there are more units in the market which either are not registered or are in the process of registration, because today we have 1000 units being launched by a single project [7].

Although the private housing companies have been playing the significant role in providing the housing facilities for the people in the Kathmandu Valley since the last few decades by constructing the high rise apartment buildings and housing units, they are more focused on providing the housing facilities for the high income group of people only. The housing facilities are yet beyond the access for the urban poor through these private housing companies because the housing companies charge more profit on the housing units to sell them. The housing companies are running the housing business for their economic benefit only rather than meeting the need of the adequate and safe housing service for the urban poor. Hence there is an instant need to address the housing problem for the urban poor in Kathmandu Valley in a proper way.

\section{METHODOLOGY \\ Research process}

In order to meet objectives of the study, different literatures related to social parameter and housing condition of urban area and rural area, housing situation and their demand in these area, Plans, policies, rules and regulations related to the housing need in context of Nepal an existing implementation condition of Janata Awash Program in Rupandehi have been collected and studied, which provided the secondary data relevant to this study.

But for this study, the group of people co related with only Janata Awash Program are considered as the low income groups, since the study is focussed on the housing needs, concept and level of housing need of for the dalits and poor musalmans who are either selected beneficiaries or non selected beneficiaries and also the implementation status of program.

\section{Study Area}

In Rupandehi, program is widely spread in to large area within (17 VDC and 4 Municipality before rearrangement of local levels).Study areas are those areas where program is scattered. 
Study areas are listed below and shown on Photo 3 [11]
1. Devdaha
5.Bodhabar
6. Karauta
9. Sktahan
2. Tilottama
7.Dhakadhai
10. Bagaha
11. Basantapur
3. Sainamaina
13. Mainahiya
14. Hatbangai
15. Binupura
16.Suryapura
17. Rayapur

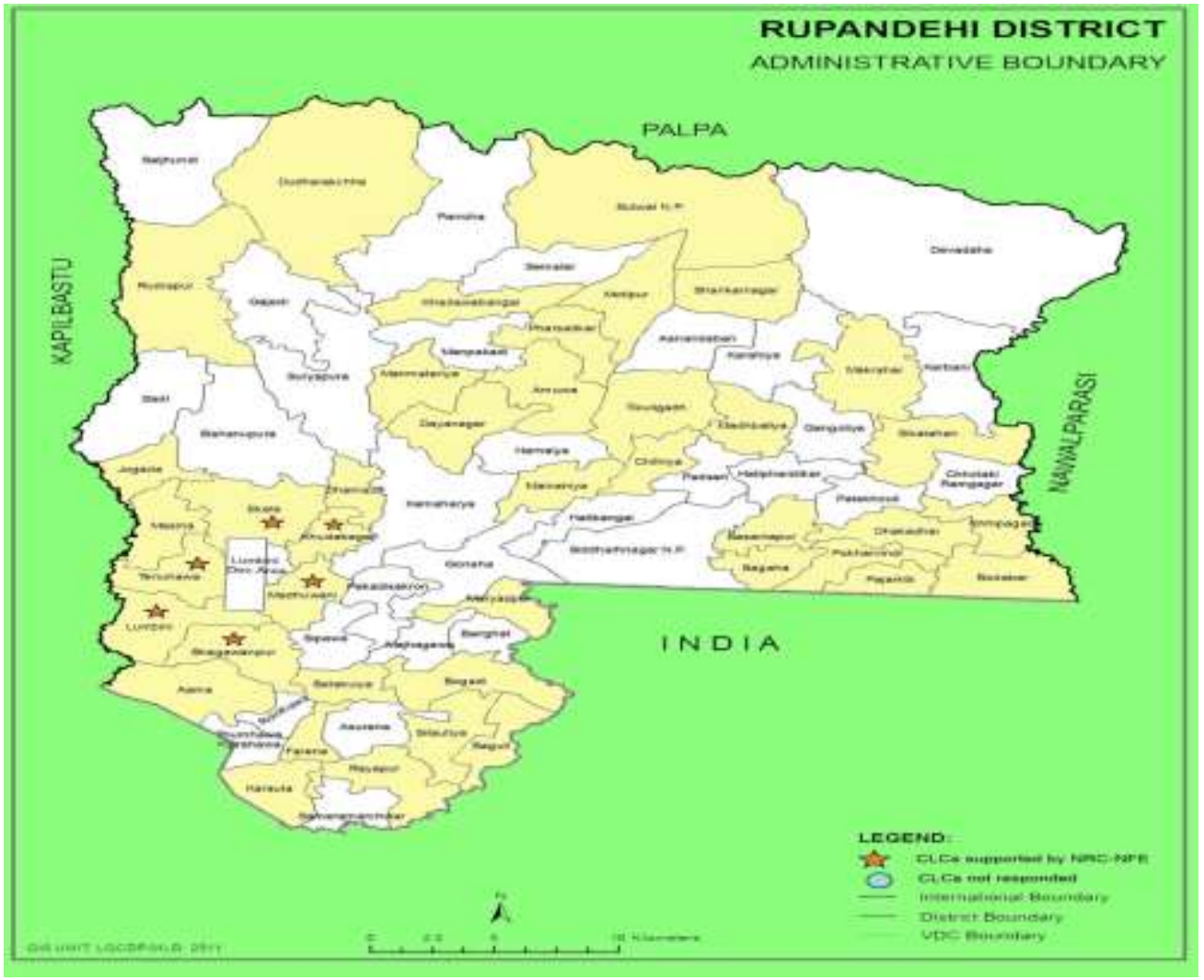

Photo-5: Map of Rupandehi District

\section{Population and Sampling}

A sample is a part of the population that was actually examined in order to gather the information of the whole population.

For this study, the files related to Janata Awash Program being implemented in Rupandehi will be reviewed at UDBO Rupandhi. Moreover diversified types of respondent will be selected. The respondent will be present and former Senior Divisional Engineers, Engineers, Sub Engineer, Social Mobilizer, Section Officer from DUDBC Rupandehi division, UDBO
Rupandehi and Ministry of Physical Infrastructure Development, Province No 5.

Local Leaders under concern local authority, selected beneficiaries, Non Selected Applicants and Construction Not Started Applicants are selected as respondents.

Out of total population total no of sample size selected for primary data collection is 99 as shown below in Table 7, set of questionnaire for different group of respondents shall be prepared and distributed.

Table-7: Details of Respondents

\begin{tabular}{|l|l|l|l|}
\hline SN & Category of Respondents & Number & Percentage \\
\hline 1 & Implementation Level Staff & 11 & 11.11 \\
\hline 2 & Local Leaders & 14 & 14.14 \\
\hline 3 & Beneficiaries Under Construction/Complete Construction & 50 & 50.51 \\
\hline 4 & Non Selected Applicants & 15 & 15.15 \\
\hline 5 & Construction Not Start Applicants & 9 & 9.09 \\
\hline & Total & 99 & 100 \\
\hline
\end{tabular}




\section{DATA COLLECTION}

Both the primary data and the secondary data were collected to carry out this study. To fulfil the objective of the study, the primary data were obtained from the expert consultation while secondary data have been obtained from the study of National Census Reports of Nepal. The study of the plans, policies and other related document will also be carried out. The study of the National Census Reports of Nepal, plan and policies related to population growth and urbanization pattern have been focussed towards finding out the number of population, housing level and condition of Rupandehi district. The expert consultations have been focussed towards finding out the scenario of the housing need for the low income groups.

\section{Research Type}

In this study the descriptive research was also be carried out. The analytical research was helpful to find out the number of housing units required to be built for the fulfilment of the housing need in Rupandehi for dait and poor musalman. Analytical questionnaire survey was also used to find out, analyse and summarize the perception, level and condition of poor musalman and dalits in study area. RII was used to find most suitable housing need.

\section{RESULT AND DISCUSSION \\ Characteristics of Low Income Groups}

In order to fulfill the objectives of the research, the concept, level and housing need of dalits and poor musalmans groups of the study area has been studied and analyzed. The study of different characteristics were related to household size and population, Ethnic composition of the settlements, occupation, economic status, education, status of occupancy, migration, housing condition, housing type and roofing material were studied which are mentioned below:

\section{The Concept of Housing Need}

Housing demand refers to the willingness and ability to purchase a house. Housing need refers to the number of houses required, given growth in households, itself derived from household size and population growth. If those who need houses are unable to afford houses, they don't buy or demand them.

At present, 91.6 per cent and 72 per cent of the people own houses in the country and urban areas respectively. In Nepal 2.5 million new houses meaning a total of 250,000 new houses are being constructed per year and about 17 per cent $(43,653$ new units every year) of them in urban areas [5].

Rupandehi is the district on terai region of province no 5. D [8] uring study, we found a great need of proper housing for poor musalmans and dalits. Most of the dalits and musalmans are deprived from well maintained house so that we can say clearly there housing and living standard condition was extremely poor.

Housing need of Rupandehi district was partially fulfill by Janata Awash Karyakram from fiscal year $2073 / 74$ and this program is on implementation phase till the date.

\section{Household size and population}

There are total 2214 applicants households in Rupandehi district for Janata Awash Karyakram for fiscal year 2073/074, Among 2214 applicants household, 950 households having family member greater than four and 1214 households having family member less than four is shown in fig 1 .

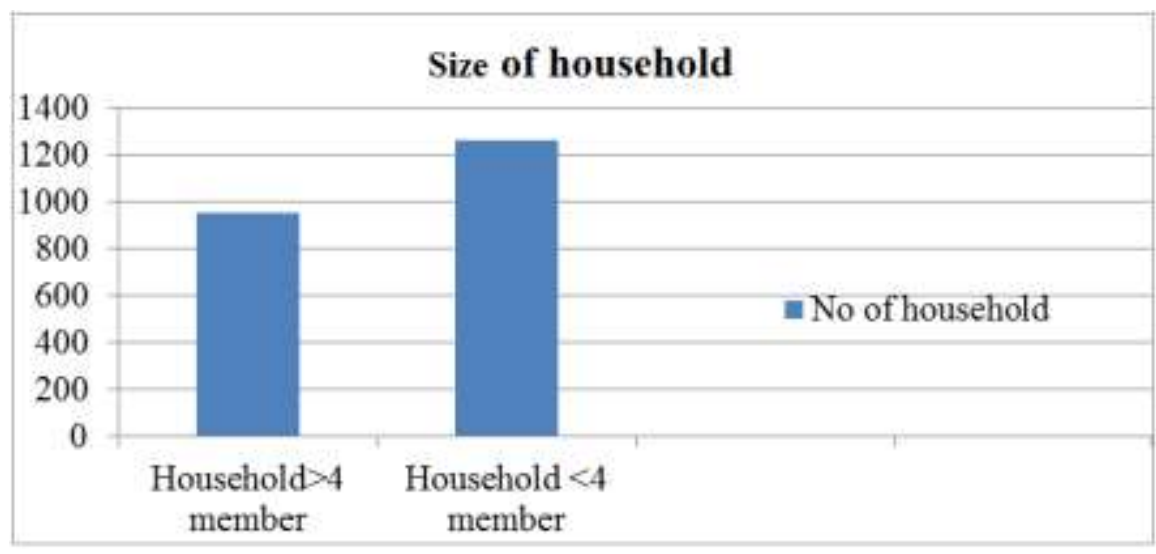

Fig-1: Household size

Source: (DUDBC Rupandehi Division)

\section{Income Status}

Income status of applicants of Rupandehi is found very poor .Among 2214 applicants; only 260 numbers of applicants have annual income more than two lakhs, where 691 and 1263 number of applicants has income less than one 1 lakhs and between 1 lakhs and 2 lakhs respectively. 
Table-8: Income Status of Applicants in Janata Awash Program 2073/074

\begin{tabular}{|l|l|l|l|l|}
\hline Annual Income & AI $<1$ lakhs & 1 lakhs $<$ AI $<2$ lakhs & AI $>2$ lakhs & Total \\
\hline Applcants Nos & 691 & 1263 & 260 & 2214 \\
\hline
\end{tabular}

Source: (DUDBC Rupandehi Division)

But in city area inside kathmandu valley of Nepal the the annual income of low income group was found as;

Most of the households (44.62\%) of Thapathali Squatter Settlement have average monthly income of NRs. 10,000 to NRs. $15,000.36 .92 \%$ of the households have monthly income of NRs. 5,000 to NRs 10,000 and $13.85 \%$ of them have monthly income less than NRs. 5000; whereas only $4.62 \%$ of them have monthly income more than NRs. 15,000 .

In Jagritinagar Squatter Settlement, most of the households $(56 \%)$ have average monthly income of
NRs. 10,000 to NRs. $15,000.34 \%$ of the households have monthly income of NRs. 5,000 to NRs 10,000 and $6 \%$ of them have monthly income less than NRs. 5000; whereas $4 \%$ of them have monthly income more than NRs. 15,000 [9].

\section{Earlier Housing Condition}

Housing condition of poor dalits and musalmans before starting the program during household direct survey conducted by DUDBC Rupandehi divison at fiscal year 2073/074 (during 2073 chaitra to 2074 jesth) was found as;

Table-9: Earlier Housing Condition (Before Program)

\begin{tabular}{|l|l|}
\hline Earlier Housing Condition & Numbers \\
\hline Condition of House & 950 \\
\hline mud wall, floor and dried grass roof & 380 \\
\hline Mud wall and CGI sheet roof & 327 \\
\hline Brick with mud mortar and dried grass type roof & 304 \\
\hline Brick with mud mortar and CGI sheet roof & 253 \\
\hline Partially mixed type of all & \\
\hline
\end{tabular}

Source: (DUDBC Rupandehi Division)

By analysis this result from survey and after evaluation of output, around 1650 i.e. more than $70 \%$ of people pass the minimum requirement to get the housing facilities by Janata Awash Program.

The pie chart of this tabulated data is shown below as:
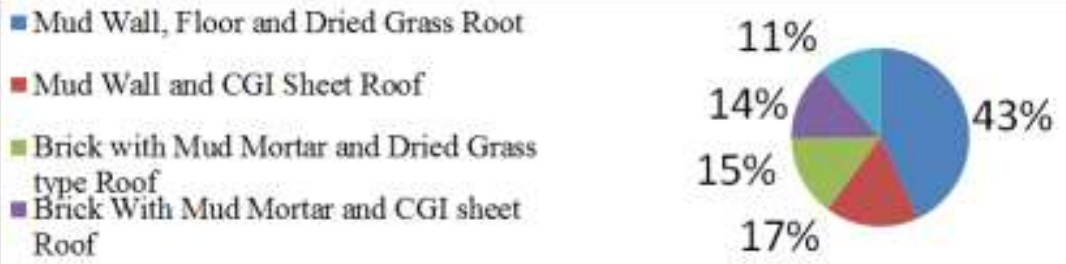

Fig-2: Earlier Housing Condition (Before Program)

\section{Land Used Condition}

Land used condition of poor dalits and musalmans before starting the program during household direct survey conducted by DUDBC Rupandehi divison at fiscal year 2073/074 (during 2073 chaitra to 2074 jesth) was found as;

Table-10: Land Used Condition

\begin{tabular}{|l|l|l|}
\hline Area of Land for home construction & \multicolumn{2}{|l|}{ Numbers } \\
\hline Sufficient quantity of land available & 1929 \\
\hline Land available but not sufficient & 184 \\
\hline No availability of land & 63 \\
\hline Dispute on land ownership & 38 \\
\hline Extra available land for agricultural purpose & Yes & No \\
\cline { 2 - 3 } & 1425 & 789 \\
\hline
\end{tabular}

Source: (DUDBC Rupandehi Division) 


\section{Level of Housing Need}

Housing need of the people is expressed based on different perspectives. Some important perspectives are discussed and presented below based on different consequences.

Table-11: Households by Ownership of House/housing Unit in Use in Rupandehi

\begin{tabular}{|l|l|l|l|l|}
\hline Total & Owned & Rented & Institutional & Others \\
\hline 163835 & 137116 & 24172 & 1219 & 1328 \\
\hline \multicolumn{5}{|c|}{ Source: (https://cbs.gov.np/) }
\end{tabular}

In Rupandehi, total no of households are 163835. Among them 137116 households have their own house, 24172 households have rented house, 1219 family have institutional house and remains 1328 have no definite housing.

Table-12: Households by Foundation of House/Housing Unit

\begin{tabular}{|c|c|c|c|c|c|c|}
\hline \multirow[t]{2}{*}{ Total } & \multicolumn{6}{|c|}{ Types of foundation } \\
\hline & $\begin{array}{l}\text { Mud bonded } \\
\text { bricks/stone }\end{array}$ & cement bonded brick/stone & RCC with pillar & Wooden pillar & Others & Not stated \\
\hline 163835 & 44772 & 67756 & 24537 & 18153 & 6493 & 2124 \\
\hline
\end{tabular}

Source: (https://cbs.gov.np/)

In Rupandehi, among 163853 houses, 44772 houses are constructed by mud bounded brick/stone foundation, 67756 houses are constructed by 67756 cement bounded brick/stone foundation, 24537 houses are constructed by RCC with column foundation, 18153 houses are constructed by wooden pillar foundation, 6493 houses are constructed by other foundation materials and 2124 houses are constructed by nonspecified foundation materials.

Table-13: Households by Roof of House/Housing Unit

\begin{tabular}{|l|l|l|l|l|l|l|l|l|}
\hline \multirow{2}{*}{ Total } & \multicolumn{6}{l}{ Roof of the House } \\
\cline { 2 - 8 } & Thatch/straw & Galvanized iron & Tile/slate & RCC & Wooden planks & Mud & Other & Not stated \\
\hline 163853 & 14665 & 25350 & 19440 & 100815 & 441 & 0 & 624 & 2500 \\
\hline
\end{tabular}

Source: (https://cbs.gov.np/)

In Rupandehi, among 163853 households, 14665 houses are of thatch/straw roof, 25350 households are of Galvanized iron roof, 19440 houses are of tile/slate roof, 100815 are of RCC roof, 441 houses are of wooden planks roof, no houses are of mud roof, 624 houses are of other materials roof and 2500 houses are of not specified materials roof.

From above these tables more than $15 \%$ of household don't have their own house.

Table-14: Households, Population and Average Household Size

\begin{tabular}{|l|l|l|l|l|}
\hline \multirow{2}{*}{ Household } & \multicolumn{4}{|l|}{ Population } \\
\cline { 2 - 5 } & Total & Male & Female & Average Household size \\
\hline 163,916 & 880,196 & 432,193 & 448,003 & 5.37 \\
\hline
\end{tabular}

Source: (https://cbs.gov.np/)

Above table shows that average size of household is 5.37 and total female population is greater than male populations. As per latest census data musalmans population is 880196 and population of dalits is more than that. A small amount of housing need in Rupandehi district is targeted to fill by Janata Awash Program i.e. 500 houses in I phase and 138 houses in II phase.

\section{Perception of the Low Income Group about their Housing Need}

The housing is one of the basic needs of the human being. The access to adequate shelter is the human right for all. So the low income groups also need the housing facility and they also have a wish to live in the adequate shelter. So this study has also intended to find out the perception of the low income groups as well as the perception of the experts and planners to fulfill the housing need of the low income groups.

The low income groups expect that the government or the donor agencies should help them financially to improve their existing housing condition. Many of the low income groups of Thapathali Squatter Settlement also do not want to move elsewhere since they do not have to pay for the shelter. They say that why to go elsewhere if we can live here free of cost. They say so because they are economically very weak and their education level is also low. But according to the experts and planners the rental housing would be the 
appropriate approach and it should be initiated by the Government of Nepal with the support of NGOs and private housing companies. The Government alone cannot fulfill the housing need of the low income groups in a sustainable way [8].

There are many factors that influence the housing need for the low income groups in the urban areas. However the important that influence the housing need of low income groups in Kathmandu Valley have been considered in this study such as Family's income, access to the occupation, access to the market area, neighborhood and community attachment, geographical location, place of living currently, composition of new settlement, land price and cost of building construction. The Relative Importance Index has also been applied to find the most important factors that influence the housing need for the low income group in the Kathmandu Valley [8].

In Rupandehi, the result from RII based on different factors of housing need are as below in table 15 and their comparison are shown in figure 3.

Table-15: Ranking of Important Factors Influencing the Housing Need

\begin{tabular}{|l|l|l|l|l|l|l|l|l|l|l|}
\hline \multirow{2}{*}{ S.N. } & \multirow{2}{*}{ Factors } & NSA & \multicolumn{2}{l|l}{ HCB } & \multicolumn{2}{l|}{ CNSA } & \multicolumn{2}{l|}{ Average Importance } \\
\cline { 3 - 10 } & & RII & Rank & RII & Rank & RII & Rank & RII & Rank \\
\hline a & Family's income & 33.333 & $5^{\text {th }}$ & 71.2 & $4^{\text {th }}$ & 0 & $5^{\text {th }}$ & 34.84 & $5^{\text {th }}$ \\
\hline b & Easy access to the family's occupation & 45.333 & $3^{\text {rd }}$ & 54 & $6^{\text {th }}$ & 0 & $5^{\text {th }}$ & 33.11 & $6^{\text {th }}$ \\
\hline c & Easy access to the market area & 45.333 & $3^{\text {rd }}$ & 59.6 & $5^{\text {th }}$ & 48 & $3^{\text {rd }}$ & 50.97 & $4^{\text {th }}$ \\
\hline d & $\begin{array}{l}\text { Neighborhood and community } \\
\text { attachment }\end{array}$ & 78.667 & $1^{\text {st }}$ & 76.8 & $3^{\text {rd }}$ & 90 & $1^{\text {st }}$ & 81.82 & $1^{\text {st }}$ \\
\hline e & Geographical location & 40 & $4^{\text {th }}$ & 82.2 & $2^{\text {nd }}$ & 68 & $2^{\text {nd }}$ & 63.4 & $3^{\text {rd }}$ \\
\hline f & Place of living currently & 70.667 & $2^{\text {nd }}$ & 83.6 & $1^{\text {st }}$ & 68 & $2^{\text {nd }}$ & 74.08 & $2^{\text {nd }}$ \\
\hline g & Composition of new settlement & 0 & $6^{\text {th }}$ & 5.2 & $7^{\text {th }}$ & 6 & $4^{\text {th }}$ & 3.73 & $7^{\text {th }}$ \\
\hline h & $\begin{array}{l}\text { Land price and Construction cost of } \\
\text { housing }\end{array}$ & 0 & $6^{\text {th }}$ & 0 & $8^{\text {th }}$ & 6 & $4^{\text {th }}$ & 2 & $8^{\text {th }}$ \\
\hline
\end{tabular}

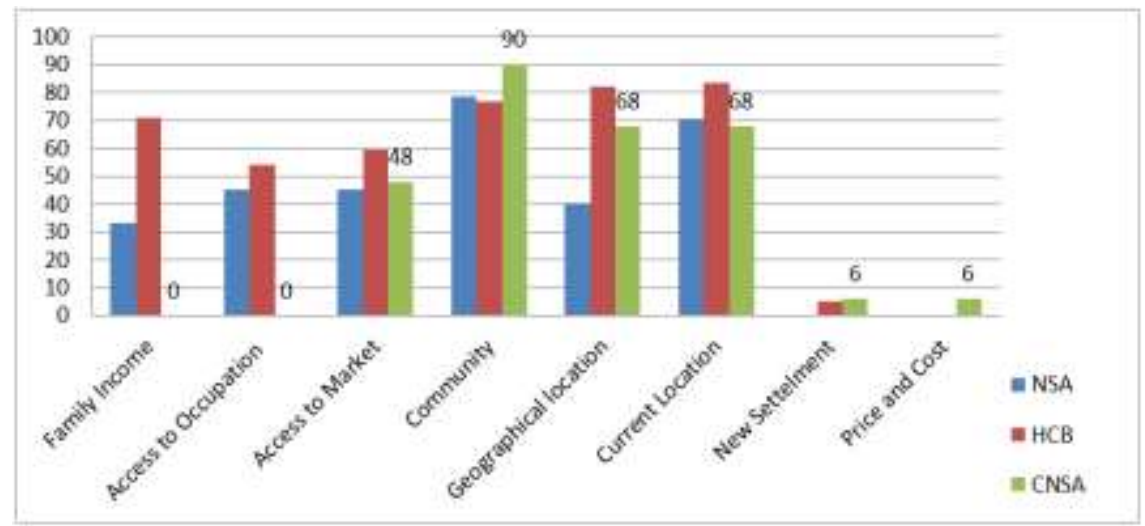

Fig-3: Different Factor Influencing Housing Need

This result of RII based on housing need was found as drastically different from the Kathmandu valley. Here, our study finally conclude that the poor musalmans and dalits wants to live with neighborhood and community attachment because they are emotionally attached with community and that place where they birth, play and still living and another most important factor is geographical location, really they don't want to live their life on another region basically due to climatic factor and community aspects.

\section{Opinion and View about Program} Opinion of Local Leader

All local leader expressed their view about program is too much appropriate and more other peoples of all ethnic groups should be included in the program as much as possible and also Selection process is fully trustworthy and people are satisfied from this program. Table 20 shows the details view about opinion of local leaders are shown below on table 16 as:

Table-16: Opinion about Program by Local Leader

\begin{tabular}{|c|c|c|}
\hline \multicolumn{3}{|l|}{ Opinion About Program by Local Leader } \\
\hline Opinion About Program & Frequency & Opinion in percentage \\
\hline a. Is in favor of dalit and poor musalmans & 3 & $21 \%$ \\
\hline b. This government effort deserves appraisal & 3 & $21 \%$ \\
\hline c. At least some people are benefited & 7 & $50 \%$ \\
\hline d. Others : Include all group & 1 & $8 \%$ \\
\hline
\end{tabular}

Housing Condition of Applicants 
Condition of targeted group of people in Rupandehi before starting program was found as Poor condition (with mud floor/ Unhygienic living condition/ poor infrastructure) from questionnaire survey as shown in table 17 below.

\section{Table-17: Condition of Targeted Group of People in Rupandehi before Starting Program in View of} Implementation Level Staff

\begin{tabular}{|l|l|l|}
\hline $\begin{array}{l}\text { Condition of Targeted Group of People in Rupandehi Before } \\
\text { Starting Program }\end{array}$ & Frequency & $\begin{array}{l}\text { Result in } \\
\text { percentage }\end{array}$ \\
\hline $\begin{array}{l}\text { Poor condition (with mud floor/ Unhygienic living condition/ poor } \\
\text { infrastructure) }\end{array}$ & 11 & $100 \%$ \\
\hline $\begin{array}{l}\text { Fair condition (with cement floor/ Unhygienic living condition/ } \\
\text { good infrastructure) }\end{array}$ & 0 & 0 \\
\hline $\begin{array}{l}\text { Good condition (with cement floor/ Hygienic living condition/ } \\
\text { good infrastructure) }\end{array}$ & 0 & 0 \\
\hline
\end{tabular}

Table-18: Existing Housing Condition of Non Selected Applicants

\begin{tabular}{|l|l|l|}
\hline Existing Housing Condition of Non Selected Applicants & Frequency & Result in percentage \\
\hline $\begin{array}{l}\text { Poor condition (with mud floor/ Unhygienic living } \\
\text { condition/ poor infrastructure) }\end{array}$ & 11 & $100 \%$ \\
\hline $\begin{array}{l}\text { Fair condition (with cement floor/ Unhygienic living } \\
\text { condition/ good infrastructure) }\end{array}$ & 0 & 0 \\
\hline $\begin{array}{l}\text { Good condition (with cement floor/ Hygienic living } \\
\text { condition/good infrastructure) }\end{array}$ & 0 & 0 \\
\hline
\end{tabular}

As per sample taken for the study (non selected applicants) all of them housing condition were found as poor condition but as per the data evaluated from the household survey poor housing condition was only $65 \%$.

\section{CONCLUSION}

We came conclude that 16.38 percentage of household still don't have their own house and 32.5 percentages of houses are of poor and unhygienic condition in Rupandehi and really they need safe housing facilities.Average household size of Rupandehi district is found as 5.37, but in program scattered and targeted area house hold size greater than four is found as $54.83 \%$ and household size less than four is found as $45.16 \%$ (based on total applicants for a program).Income status of applicants of Rupandehi is found very poor. Among 2214 applicants; only 260 numbers of applicants have annual income more than two lakhs, where 691 and 1263 number of applicants have income less than one 1 lakhs and between 1 lakhs and 2 lakhs respectively. A small quantity $(2.38 \%$ of total homeless household) of housing need in Rupandehi district was targeted to fill by Janata Awash Program ie. 500 houses in I phase and 138 houses in II phase which is in very less in quantity in comparison with housing demand.Most of the local leader and selected beneficiaries expressed their view about program is very good program and it will be extended in future in large number as much as possible for all group (not only dalit and musalmans) and they are fully satisfied from this program and happy. The major factors of housing need are found as: Neighborhood and community attachment, Place of living currently, Geographical location, Easy access to the family's occupation, Family's income respectively to importance.

\section{RECOMMENDATIONS}

We can recommend that; Until today madhesis and dalits or poverty stricken musalmans are lagging behind compared to other dominant caste and groups. So it very urgent to facilitate them with safe residence and empower them in terms of social and health status.Janta Awaas has been working in building new houses for some but are not adequate as we have seen so far. We have incorporated this finding in our conclusion. It may not be possible to build new houses for everyone, from the alternative approaches study to address their housing needs; new programs can be launched for long term resolution to this issue.

\section{REFERENCES}

1. DUDBC, R. D. (2076). Progress Report 2075/076. Rupandehi,Nepal: DUDBC,Rupandehi Division.

2. NLSS, 2. (2012). National Living Standard Survey (NLSS). Kathmandu, Nepa: Government of Nepal.

3. NUDS, 2. (2015). National Urban Development Strategy (NUDS).: Kathmandu, Nepal: Government of Nepal (GoN ), Ministry of Urban Development.

4. NSP, 2. (2012). National Shelter Policy 2012. Kathmandu, Nepal: Government of Nepal (GoN), Ministry of Urban Development.

5. Mishra, A.K. (2019). Housing Needs Fulfillment for Low -Income Group , LivaS: International Journal on Livable Space, 4(2), September 2019: 40-47

Doi:

http://dx.doi.org/10.25105/livas.v4i2.5630

[40]Availablefrom:https://www.researchgate.net/pu 


\section{blication/337649307_HOUSING_NEEDS_FULFI LMENT_FOR_LOW-INCOME_GROUP [accessed Aug 23 2020].}

6. Gilroy, P. (2004). After empire: Melancholia or convivial culture?. Routledge.

7. Rajbhandari, O. (2009). Housing Scenario of Nepal. Nepal: Society of Consulting Architects and Engineers Firms (SCAEF.

8. Shah, S.K., \& Mishra A.K. (2018). Review on Global Practice of Housing Demand Fulfilment for Low Income Group People, NOLEGEIN Journal of Business Ethics, Ethos \& CSR eISSN: 2581-5601 Vol. 1: Issue 2 www.mbajournals.in Availablefrom:https://www.researchgate.net/public
ation/329164106_Review_on_Global_Practice_of_ Housing_Demand_Fulfilment_for_Low_Income_G roup_People [accessed Aug 23 2020].

9. Mishra. A. K., \& Shah. S.K. (2018). Estimating Housing Unit for Low Income Group of People in Kathmandu, Nepal. NOLEGEIN Journal of Operations Research \& Management, 1(2).

Availablefrom:https://www.researchgate.net/public ation/329150451_Estimating_Housing_Unit_for_L ow_Income_Group_of_People_in_Kathmandu_Ne pal [accessed Aug 23 2020].

10. (https://study.com/academy/lesson/types-ofhousing-overview-examples.html). 